\title{
Nutritional Effects of Weaning Flour 'Anagobaka' on Young Rats Wistar
}

\author{
Kouakou Egnon K. V., ", Bouafou Kouamé G. $\mathbf{M}^{2}$, Meité Alassane ${ }^{1}$, Kouamé K. Gustave ${ }^{1}$, \\ Kati-Coulibaly Séraphin ${ }^{1}$ \\ ${ }^{1}$ Laboratory of Nutrition and Pharmacology, Faculty of Biosciences, University Félix Houphouët-Boigny, Abidjan, Ivory Coast \\ ${ }^{2}$ Natural sciences, Normal superior school, Abidjan, Ivory Coast
}

Email address:

kouakouegnonvivien@yahoo.fr, (K. Egnon)

${ }^{*}$ Corresponding author

\section{To cite this article:}

Kouakou Egnon K. V., Bouafou Kouamé G. M, Meite Alassane, Kouame K. Gustave, Kati-Coulibaly Séraphin. Nutritional Effects of Weaning Flour 'Anagobaka' on Young Rats Wistar. Science Journal of Public Health. Special Issue: Addiction and Substance Abuse. Vol. 4, No. 5-1, 2016, pp. 12-16. doi: 10.11648/j.sjph.s.2016040501.13

Received: June 25, 2016; Accepted: July 28, 2016; Published: September 3, 2016

\begin{abstract}
This project aims at determining the nutritional effects of Anagobaka on young wistar rats. These results have been composed to an infant weaning flour (Cerelac wheat) and a control diet made of fish flour. Rats have been fed during 15 days. The results of the chemical analysis have proved that Anagobaka contains $2.04 \pm 0.03 \%$ of protein, $6.04 \pm 0.11 \%$ of lipids and $82.1 \pm 0.94 \%$ of carbonate with an energetic value of $390.32 \mathrm{kcals}$. These results have been compared respectively to the "Cerelac wheat" with $14.94 \pm 0.16 \%$ of protein, $6.04 \pm 0.11 \%$ of lipid, $66,6 \pm 0,12 \%$ of carbohydrate and 434.01 kcals and to the control diet with $14.94 \pm 0.9 \%$ of protein, $8.8 \pm 0.66 \%$ of lipids, $72.2 \pm 0.28 \%$ of carbohydrate and 427.76 kcals. Viewing the nutrition, we notice that the growth, the gain in weight, the Food Coefficient (FC), the Protein Coefficient (PC) and the Apparent Digestibility (AP) are inferior to that of "Cerelac wheat" and to the control diet. Thus the presence of Anagobaka has occasioned the emaciation of $-0,97 \mathrm{~g} / \mathrm{day}$ on young rats.
\end{abstract}

Keywords: Anagobaka, Emaciation, Nutritional Effects, Young Rats

\section{Introduction}

From birth to the age of six months, all the nutritional needs of children are covered by mother's milk [2, 5, 18]. Beyond this age, mother's milk does not cover entirely energetic and protein needs $[14,13,20]$. It is the weaning period that goes from six months to two years. During that period, it is necessary to give the child liquid or semi liquid food to compensate mother's milk. These complement foods should bring, in balanced proportion, major nutriments such as proteins, lipids and carbohydrates [5, 10].

Among these weaning flours, there is Anagobaka. It is used by middle class mothers, as a complement food for infants. Unfortunately, this flour seems not to correspond to the norms of weaning. The first investigations made in health Centre, on children who came for consultation showed some signs of malnutrition on these children. In order to know if this malnutrition is caused by Anagobaka (milk custard) this survey has been made. It aims at determining the nutritional effects of Anagobaka through an experiment on rats Wistar and compare them. To those of the flour cereals' wheat and the control diet.

\section{Materials \& Methods}

\subsection{Materials}

\subsubsection{Animals and Dwellings}

The animals are Wistar male rat's aged between 45 and 50 days, with an average weight of $56.25 \mathrm{~g}$, and coming from the animal center of the nutritional laboratory of (UFR biosciences, university Felix Houphouet-Boigny of Abidjan). The rats are dwelt in cages made with grid which permit to retain animal wastes upstream and collect urines downstream, which dumps in bottles through funnel. Cages are provided with feeding bottles to feed and make animals drink. These cages are in a room with a hygrometry degree 
from $70 \%$ to $80 \%$ and a temperature of $25^{\circ} \mathrm{C}$.

\subsubsection{Diets}

Three weaning flours have been submitted to growing rats (Anagobaka and Cereals wheat of nestle) and control diet flour (Table 1). Cerelac wheat of Nestle is a weaning flour. This infant weaning flour of Nestlé is popular on African market. It has a very good image in terms of mark [8]. It is made and sold in Ivory Coast. The price of cereals wheat of Nestlé varies between $250 \mathrm{fcfa}$ and $350 \mathrm{fcfa}$ ( $50 \mathrm{~g}$ cachet).

Anagobaka (a malinké word which means Anago people's porridge) is an infant flour. It is sold in plastic pots of $400 \mathrm{~g}$ and $1200 \mathrm{~g}$. The control diet is made of white maize flour and maize oil which constitutes the source of energy. Hareng fish flour constitutes the source of animal protein. The whole is completed by a mixture of vitamins and minerals.

\subsection{Methods}

\subsubsection{Chemical Analyses (Table 1)}

\section{Humidity Rate}

It is determined by steaming at $70^{\circ} \mathrm{C}$ until obtaining an important mass of the experiment sample.

\section{Protein Rate}

The proteins of solid and liquid products have been measured out according to kjedahl technique, with a coefficient of azote conversion in protein equal to 6,25 .

\section{Fat Rate}

The fat is extracted after boiling $5 \mathrm{~g}$ of the sample in a machine of soxhlet at $80^{\circ} \mathrm{C}$. After evaporation of hexane the machine (rotavapor) the ball is cooled Doan and weighed [18].

\section{Ash rate}

The Content in ash is obtained by weighing $5 \mathrm{~g}$ of the sample incinerated at $550^{\circ} \mathrm{C}$ during 24 hours in an oven (select horn, pselecta) [3].

\section{Content in Mineral}

The zinc the iron and calcium are measured out by the filtrate of the ash of the sample [3].

\section{Determination of Energy}

The energy of a diet is the sum of products of each major element (carbohydrates, proteins, lipids) and its thermal coefficient.

Table 1. Chemical composition of the three diets.

\begin{tabular}{llll}
\hline & Anagobaka & Cerelac wheat & Control group \\
\hline Proteins g/100 g DS & $2.04 \pm 0.03^{\mathrm{a}}$ & $14.94 \pm 0.16^{\mathrm{b}}$ & $14.94 \pm 0.9^{\mathrm{b}}$ \\
carbohydrates g/100 gDS & $82.1 \pm 0.94^{\mathrm{a}}$ & $66.6 \pm 0.12^{\mathrm{b}}$ & $72.2 \pm 0.28^{\mathrm{b}}$ \\
Fat g/100 g DS & $6.04 \pm 0.11^{\mathrm{a}}$ & $12.0 \pm 0.8^{\mathrm{b}}$ & $8.8 \pm 0.06^{\mathrm{b}}$ \\
Energy Kcal/100 g DS & $390.32^{\mathrm{a}}$ & $434.01^{\mathrm{b}}$ & $427.76^{\mathrm{b}}$ \\
Iron mg/100 g MS & $3.08 \pm 0.05^{\mathrm{a}}$ & $7.6 \pm 0.27^{\mathrm{b}}$ & $6.25 \pm 0.02^{\mathrm{b}}$ \\
Calcium g/100 g DS & $97.34 \pm 0.64^{\mathrm{a}}$ & $430 \pm 0.94^{\mathrm{b}}$ & $402 \pm 0.05^{\mathrm{b}}$ \\
Zinc g/100 g DS & $1.35 \pm 0.04^{\mathrm{b}}$ & $1.8 \pm 0.00^{\mathrm{b}}$ & $2.35 \pm 0.23^{\mathrm{b}}$ \\
\hline
\end{tabular}

Each reading is the average followed by the examination of three tests. There is not important difference between two readings of the some line marked by the same letter.

Dry Substace: D.S

\subsubsection{Animal Grouped Animal Experiment}

For each diet (Anagobaka, Cerelac wheat, control group) corresponds a group of is ten young rats. The animal experiment made according to [1] method involves two phases: a growth experiment which lasted 15 days and an azote assessment which was made on the last five days.

\section{Experiment and Measures Performed}

Diets are served ad libitum once a day (at $7 \mathrm{~h} 30$ in morning) on a paste form to avoid wasting. The water is served and renewed in an interval of three days. Animals are weighed before the experiment and then, each three days. The last weighing took place at the end of the experiment. The growth is determined by the difference between the initial weights. The difference between the quantity of food that has been served and the leftovers allows to determine the quantity of food that has been consumed. During the experiment of azote assessment, urines and animal wastes are collected each day. They are weighed and then conserved at$10^{\circ} \mathrm{C}$ for analyses.

\section{Expressing the Parameters of the Nutritional Study}

The parameters of the nutritional study are registered in the

Table 2. Expressing the parameters of the nutritional study.

\begin{tabular}{ll}
\hline Parameter & Mathematical Expressions \\
\hline Dry Substance (D.S)g/d & Total amount of dry substance ingested \\
during the experimental period. \\
Total Protein (T.P) g/d & P.T $(\mathrm{g})=\mathrm{D} . \mathrm{S}$ x\% Protein of diet \\
Growth in weight (G.W) g/d & Final weight- initial weight/number of days \\
Food Coefficient (F.C) & F.C $=$ G.W $(\mathrm{g}) /$ D.S $(\mathrm{g})$ \\
Protein Efficient (P.E) & P.E $=$ G.W (g) $/$ T.P (g) \\
Apparent Digestibility (A.D) & A.D $=(\mathrm{I}-\mathrm{F}) / \mathrm{I}$ x 100 \\
\hline
\end{tabular}

F: protein excreted from the wastes of a rat fed with the diet. g/d: gram/day, I=T.P/6.25

\section{Statistical Analysis}

The analysis of data has been made by the software statistical version 6.0 the comparison of averages has been made by the test of student Newman-keels at a rate of $5 \%$. 


\section{Results}

\subsection{Growth Parameters}

\subsubsection{Dry Substance Used}

The dry substance used is estimated at $7.93 \pm 1.25 \mathrm{~g} / \mathrm{d}$ for Anogobaka. Whereas the control diet and the Cerelac wheat have respectively a value of $7.48 \pm 0.86 \mathrm{~g} / \mathrm{d}$ and $7.38 \pm 0.85$ $\mathrm{g} / \mathrm{d}$. Not important difference has been observed between the three groups of vats consuming the diets.

\subsubsection{Total Protein Used}

The rate of protein obtained from Anagobaka $0.1 \pm 0.50 \mathrm{~g} / \mathrm{d}$ is considerably inferior $(\mathrm{P} \leq 0.05)$ to those of Cerelac wheat $(1.12 \pm 0.30 \mathrm{~g} / \mathrm{d})$ and the control diet $(1.10 \pm 0.6 \mathrm{~g} / \mathrm{d})$. However, the control diet and the Cerelac wheat do not show an important difference $(\mathrm{P} \geq 0.05)$ between them.

\subsubsection{Growth in Weight in the three Groups of Rats}

The control of weights has permitted to evaluate the animal's health. Anagobaka occasions a decrease in weight until the ninth day, and a slight positive evolution in the last week. Contrary to Anagobaka, Cerelac wheat and the control diet have occasioned a positive growth in weight on rats. Figure 1.

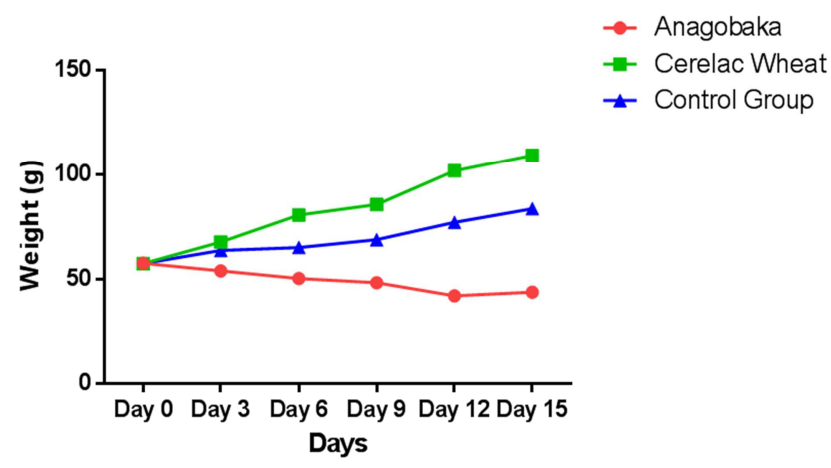

Figure 1. Growth in weight in the three groups of rats.

\subsubsection{Growth in Weight}

Anagobaka has a negative action on growth in weight $(-0.97 \pm 0.38 \mathrm{~g} / \mathrm{d})$. However the Cerelac wheat and the control diet have respectively occasioned a growth in weight $1.78 \pm 0.44 \mathrm{~g} / \mathrm{d}$ and $3.69 \pm 0.43 \mathrm{~g} / \mathrm{d}$. the results are very different $(\mathrm{P} \leq 0.05)$ (Table 3$)$.

\subsubsection{Food Coefficient}

Table 3. Growth parameters of rats consuming the different diets.

\begin{tabular}{llll}
\hline & Anagobaka & Cerelacwheat & Control group \\
\hline DS (g/d) & $7.94 \pm 0.88^{\mathrm{a}}$ & $7.48 \pm 0.88^{\mathrm{a}}$ & $7.32 \pm 0.54^{\mathrm{a}}$ \\
$\mathrm{TP}(\mathrm{g} / \mathrm{d})$ & $0.16 \pm 0.50^{\mathrm{a}}$ & $1.12 \pm 0.30^{\mathrm{b}}$ & $1.10 \pm 0.6^{\mathrm{b}}$ \\
$\mathrm{GW}(\mathrm{g} / \mathrm{d})$ & $-0.97 \pm 0.38^{\mathrm{a}}$ & $3.69 \pm 0.43^{\mathrm{b}}$ & $1.78 \pm 0.44^{\mathrm{c}}$ \\
$\mathrm{FC}$ & $-0.12 \pm 0.04^{\mathrm{a}}$ & $0.48 \pm 0.04^{\mathrm{b}}$ & $0.23 \pm 0.06^{\mathrm{c}}$ \\
$\mathrm{PC}$ & $-6.21 \pm 3.02^{\mathrm{a}}$ & $3.25 \pm 0.28^{\mathrm{b}}$ & $1.62 \pm 0.41^{\mathrm{c}}$ \\
\hline
\end{tabular}

Each reading is the average followed by the examination of three tests. a,b,c: there is no significant difference between two values of the some line topped with the some letter.

Anagobaka has a negative food coefficient $(-0.09 \pm 0.07)$. The food coefficient of the control diet $(0.24 \pm 0.06)$ is superior to that of Anagobaka and inferior to that of Cerelac wheat $(0.48 \pm 0.04)$. The Food Coefficients of the three diets are very different, $(\mathrm{P} \leq 0.05)$ between them (Table 3$)$

\subsubsection{Protein Coefficient}

The protein coefficient of the different diets Anagobaka, control diet and Cerelac wheat are respectively $-6.21 \pm 3.02$; $1.62 \pm 0.41 ; 3.25 \pm 0.28$. The protein coefficient of the foods are very different $(\mathrm{P} \leq 0.05)$.

\subsection{Digestion of Proteins}

The digestion of protein is estimated at $80.83 \pm 2.77 \%$ for Cerelac wheat, $80.85 \pm 3.37 \%$ for the control diet and $66.17 \pm 24.30 \%$ for Anagobaka. There is no important difference between the three $((\mathrm{P} \geq 0.05)$. (Figure 2$)$.

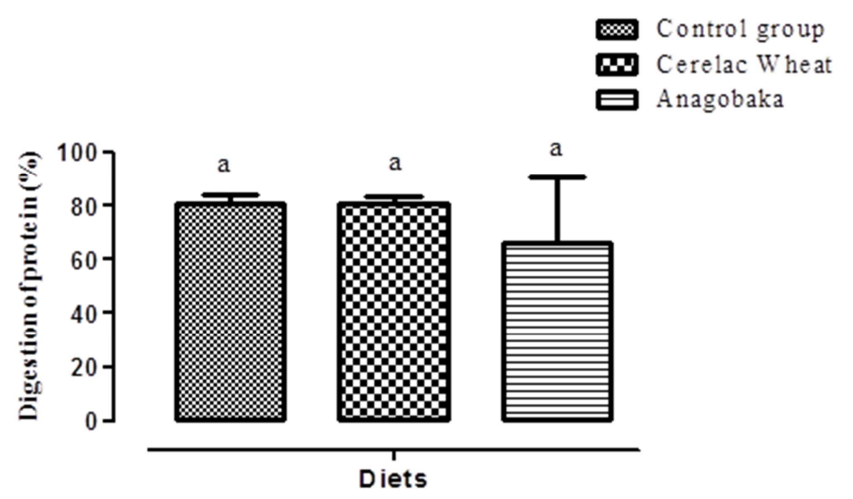

Figure 2. Apparent digestibility of rats subjected to experimental diets.

Each value is the mean $\pm \mathrm{SD}$ of 10 rats. a: there is no significant difference between two values of the histogram topped with the same letter.

\section{Discussion}

This study is based on two conventional approaches. Growth parameters and chemical analysis have permitted to appreciate the nutritional characteristics of Anagobaka, Cerelac wheat and the control diet.

The differences observed between the quantities of food eaten by the rats are not important $((\mathrm{P} \geq 0.05)$. However, for rats fed with Anagobaka, the food consumed ( $7.94 \pm 0.88 \mathrm{~g} / \mathrm{d})$ is slightly superior to that of animals fed with Cerelac wheat $(7.48 \pm 0.88 \mathrm{~g} / \mathrm{d})$ and the first experiment diet $(7.32 \pm 0.88 \mathrm{~g} / \mathrm{d})$. Anagobaka seems to be more appreciated than Cerelac wheat and the control diet.

This can be due to many reasons (flavor, taste, color, texture and chemical composition of diet in nutriments). Thus, the taste, the color, the flavor and texture have an important role in the appreciation of infant flour [16]. The important use of Anagobaka by young rats occasioned an emaciation $(-0.97 \pm 0.38 \mathrm{~g} / \mathrm{d})$ contrary to a growth in weight observed on rats fed with Cerelac wheat $(3.65 \pm 0.43 \mathrm{~g} / \mathrm{d})$ and the control diet $(1.77 \pm 0.44 \mathrm{~g} / \mathrm{d})$. This emaciation on rats fed with Anagobaka can be explained by the poor content in nutriments. In fact, the chemical analysis of diets have 
proved that the content in nutriments of Anagobaka is weaker than those of Cerelac wheat and the control diet. Thus the content in protein and lipid of Anagobaka are respectively $2.04 \pm 0.03 \mathrm{~g} / \mathrm{DS}$ and $6.04 \pm 0.01 \mathrm{~g} / 100 \mathrm{gDS}$ compared to the control diet (Protein 14.94 $\pm 0.9 \mathrm{~g} / 100 \mathrm{gDS}$ and lipids $12 \pm 0.01 \mathrm{~g} / 100 \mathrm{gDS})$. However, Anagobaka presents an important quantity of carbohydrate $(82.1 \pm 0.94 \mathrm{~g} / 100 \mathrm{~g}$ DS) compared to Cerelac wheat $(66.6 \pm 0.12 \mathrm{~g} / 100 \mathrm{~g}$ DS $)$ and the control diet $(72.2 \pm 0.28 \mathrm{~g} / 100 \mathrm{gDS})$, but an energy value (390.32kcal/100g MS) significantly below Cerelac wheat $(434.01 \mathrm{kcal} / 100 \mathrm{~g} \mathrm{DS})$ and control diet $(427.76 \mathrm{kcal} / 100 \mathrm{~g}$ DS).

Anagobaka is poor in protein $(2.04 \pm 0.03 \mathrm{~g} / 100 \mathrm{~g}$ DS $)$ and presents a weakness in acids required for growth. This weakness occasions an emaciation on rats which consumed Anagobaka. In fact, proteins cannot be replaced by carbohydrate and lipids [12].

Thus, food containing less than $3 \%$ of protein cannot cover needs in protein even if they are used in great quantity [11] Generally, a lack in protein leads to a retardation of growth and a loss in weight [9].

The emaciation of rats which consumed Anagobaka is due to the weakness of protein contained in Anagobaka. Authors such as $[17,8]$ have made similar remarks with young children who consumed a meal called «Poto-Poto» rich in carbohydrate but poor in energy and protein. This meal is made of Maize or cassava.

Anagobaka seems to have the same characteristics with «Poto-Poto». On the same way, the growth parameters clearly show the bad quality of proteins contained in Anagobaka.

The food coefficient $(-0.12 \pm 0.04)$ and the protein coefficient $(-6.21 \pm 3.02)$ are poor.

The food coefficient of these meals range as follow: Anagobaka $(-0.12 \pm 0.07)$ first experiment diet $(0.23 \pm 0.06)$ and Cerelac wheat $(0.48 \pm 0.04)$. These results present Anagobaka as the weakest food. The negative food coefficient of Anagobaka (-0.12 \pm 0.07$)$ explains its inability to foster a growth in weight on rats.

In this study, the protein coefficient of Anagobaka ($6.21 \pm 3.02)$, control diet $(1.62 \pm 0.11)$ and Cerelac wheat $(3.25 \pm 0.28)$ are very different $\mathrm{P} \leq 0.05$. The negative protein coefficient of Anagobaka confirms the misuse of the protein of this food.

Also, Anagobaka has a weak content of lipid (6.04g/100gMS) and energy (390Kcal/100gMS). Lipids are important energy source and also provide with essential fat acids. Lipids play an important role for satiety and growth in weight [4].

A food poor in energy and lipid leads to a loss in weight [6]. Our study show that Anagobaka is poor in lipid and protein and that leads to a continuous loss in weight despite the important concentration of carbohydrates.

[10] have made the same remarks in their survey about the nutritional value of normal bread and composite bread containing citrillus lanatus.
However, these results are under those obtained with soya flour and fish flour which are usual proteins used for animal experiment $[5,6,20]$. The chemical profile of Anagobaka could disturb the growth of those who consume it. Foody whose digestion is under $70 \%$ are unable to assure the needs of energy even if they are distributed ad libitum [19]. The digestion values of Anagobaka (66.17\%), Cerelac wheat $(80.83 \%)$ and the control diet $(80.85 \%)$ confirm these remarks and explain the weakness and the loss in Wight of rats who consumed Anagobaka.

All these parameters, linked to the growth and the chemical composition have allowed to evaluate the nutritional quality of the different diets, and especially that of Anagobaka.

\section{Conclusion}

This study has permitted to compare the nutritional effects of Anagobaka. To those obtained with Cerelac wheat and a control diet made of fish flour. The food used, the growth in weight, the food and protein coefficients and the protein digestion have been determines. These parameters have revealed that Anagobaka has inferior a nutritional value to those of Cerelac wheat and the control diet. Thus, as young rats demand less essential acids than babies, these results could better explain the growth retardation observed with children consuming Anagobaka as weaning meal. However, additional studies are necessary to well appreciate the impact of Anagobaka on rats, so that to deduct its effects on children.

\section{Acknowledgments}

Authors of this article would like to thank the head of the Laboratory of Nutrition and Pharmacology at the University Felix Houphouet Boigny (Ivory Coast).

\section{References}

[1] Adrian, R. M. and R. Frangne. (1991). Techniques d'analyse nutritionnelle. In: Principes de techniques d'analyse. Ed. Lavoisier TEC \& DOC Paris, 451-478.

[2] Akre. (1989). Alimentation infantile. Bases physiologiques. Bulletin del'Organisation mondiale de la Santé, (suppl.), 67p.

[3] Beaufrère, 1993. Evaluation du métabolisme protéique, in: Traité de Nutrition Pédiatrique, 14: 421-436.

[4] Benyoub. (2011). Détermination de quelques paramètres biochimiques chez la rate wistar consommant un régime cafeteria enrichie en huile de lin, Mémoire de Magister en agronomie, Université Abou BekrBelkaid Tlemcen, Algérie. 96p.

[5] Bouafou, K. K. and M. Offoumou. (2007). Bilan azotée chez le rat en croissance de la farine d'asticots séchés. Tropicultura, p 70-74.

[6] Dally, A. M, K. Kouamé, K. Bouafou and S. Kati-Coulibaly. (2010). Efficacité nutritionnelle de trois mets Ivoiriens: cabatoh à la sauce dah au nord; foutou igname à la sauce gouagouassou au centre; riz cuit à la sauce graine à l'ouest. Journal of Applied Biosciences, 33: 2084-2090. 
[7] Dijkhuizen. (2000). "Processed Complementary Foods in the World Food programFood and Nutrition Bulletin, 21 (1): 6264.

[8] Gerbouin-Rerolle. (1996). Les aliments de sevrage, Cahier de Sante, 6, 225-236.

[9] Kleinknecht, F. Terzi, M. Burtin, D. Laouari, S. Maniar. (1995). Experimental models ofnephron reduction: some answers, many questions. Kidney Int., 47: 51-54.

[10] Meite, G. Kouamé, S. Kati-Coulibaly and A. Offoumou. (2008). Étude de la valeur nutritionnelle du pain normal et des pains composites contenant de la farine de graines délipidées de Citrullus lanatus (Cucurbitacées), Bulletin de la Société Royale des Sciences de Liège, Vol. 77, pp. 80-103.

[11] Mezajoug. (2010). Propriétés nutritionnelle et fonctionnelle des protéines de tourteaux du concentrat et isolat de ricinodendron heudelotii. Bail. Pierre et Pax et tetracarpidium conophorum (Muiller Arg.). Thèse en Procédés Biotechnologie et Alimentaire. Université de Nancy, 226p.

[12] Müller, M. (2005). Review: Malnutrition and Health in developing countries. Journal of the Canadian Medical Association, 173: 279-86.

[13] Nitou; J. A.; G. Bouanga-Kalou; R. K. Niamayoua; J. M. Nzikou; S. Itoua-Okouango; M. Elenga; 3Matos L.; M. Mvoula-Tsieri; Th. Silou. (2012). Evaluation de l'état nutritionnel des mères allaitantes et de leurs nourrissons au Congo. Journal of Animal \& Plant Sciences, 2012. Vol. 13, Issue 1: 1687-1697.
[14] Pawlak, R. (1968). Influence de la supplémentation des protéines de blé par les doses croissantes de lysine sur la teneur en acides aminés libres du sang et du muscle du rat en croissance. Ann. Biol. Bioch. Biophys., 7: 517-530.

[15] Rahman, A. M, D. Mahalanabis, M. Wahed, M. Khatun and N. Majid. (1997). Absorption of macronutrients from a calorie-dense diet in malnourished children during acute shigellosis. Journal of PediatricsGastroenterol Nutrition, 24 (2): 119-123.

[16] Société Canadienne de Pédiatrie (SCP). (2013). Comité des maladies infectieuses et d'immunisation. Maternal infectious diseases, antimicrobial therapy or immunizations: Very few contraindications to breast feeding. Pediatrist Child Health, 11 (8): 489-491.

[17] Trèche. (1996). Influence de la densité énergétique et de la viscosité des bouilliessur l'ingère énergétique des nourrissons, Cahier de Sante, 6: 237-243.

[18] Tremolieres. (1977). Nutrition, Physiologies, comportement alimentaire. Ed. Dunod, Paris: 100-198.

[19] Wolter, V. J, Durix A., Letourneau J., Carcelen M. (1982). Digestibilité comparée de quatre céréales (avoine, orge, maïs, blé). Ann. Zootech., 31: 445-458.

[20] Zannou, K. B, G. Kouamé and B. Konan. (2011). Etude de la valeur nutritive de farines infantiles à base de manioc et de soja pour enfant en âge de sevrage. Bulletin de la Société Royale des Sciences de Liège, Vol. 80, 2011, p. 748-758. 